\title{
Chemical Profiles of Essential Oils and Non-Polar Extractables from Sumac (Rhus spp.)
}

\section{Sierra Rayne *}

Ecologica Research, 301-1965 Pandosy Street, Kelowna, British Columbia, Canada, V1Y 1R9

* Author to whom correspondence should be addressed: e-mail, rayne.sierra@gmail.com. 


\begin{abstract}
Sumac is the common name for a genus (Rhus) with $>250$ individual species of flowering plants in the family Anacardiaceae. These plants are globally distributed in temperate and tropical regions and can grow on marginal lands, making them strong candidates for renewable bioproduct sources. Despite the extensive historical use of some members of Rhus spp. for tannins and other commercial phenolics, little is known about the non-phenolic components of extracts and essentials oils. The current review highlights opportunities available to extend these limited prior studies to other sumac species, and for obtaining value-added compounds to complement already established phenolic extractions in these commercial plant species. To date, a number of individual aldehydes, fatty acids, long chain alcohols, terpenes and terpenoids, and waxes of commercial or bioactive potential in essential oils and non-polar extractables from selected members of the Rhus genera have been identified. Additional studies are needed to broaden the phytochemical database from other sumac species, and to better quantify the potential yields of these valuable compounds from the plants under natural and agriculturally managed conditions.
\end{abstract}

Keywords: Sumac; Rhus spp.; Phytochemicals; Non-polar; Hydrodistillation extracts; Oils 


\section{Introduction}

Sustainable multi-use crops in adaptive systems for food, material, and energy production require plant species that can provide a variety of chemical intermediates for broad-ranging commercial uses. These compounds can include sterols, flavor and aroma compounds, long-chain alcohols, fatty acids, esters, waxes, and terpenes [1-4]. Ideally, these crops would be situated near the processing facilities (i.e., biorefineries) to reduce transportation costs and associated energy and material inputs, and would be indigenous so as to not disrupt local ecosystems [5,6]. To not compete with local food production, the industrial crops should also be suitable for perennial growth without substantial water and nutrient inputs on marginal lands $[2,7]$.

Sumac (Rhus spp.) is a potentially suitable and globally distributed species [8] to help meet these sustainability goals. The plants have shallow, spreading root systems that prevent soil erosion, and can grow on poor, eroded soils [8,9]. For example, dwarf sumac $(R$. copallina), white or smooth sumac $(R$. glabra), and staghorn sumac (R. typhina) have been successfully used for erosion-control in North America over the past century [10]. Most sumac grown commercially on a global scale is $R$. coriaria in the Mediterranean and Middle East, having been cultivated for several centuries to produce a material of high quality for tanning (from polyphenolics in aqueous leaf extracts), as a food seasoning (from dried fruits), and for the promising bioactivities in various extracts [11-13].

Despite the extensive historical use of Rhus spp. (especially $R$. coriaria) for tannins and other commercial phenolics, little is known about the non-phenolic components of extracts and essentials oils. These phytochemicals have a wide range of potential commercial uses, such as medicinals, nutraceuticals, cosmetics, aroma and flavor agents for foods and beverages, pesticides, antimicrobials/antifungals/antivirals, surfactants, lubricants, waxes, and plasticizers, and as starting materials for industrial syntheses [14]. For this reason, the current mini-review has the objective of highlighting opportunities available to extend these studies to other sumac species, and for obtaining value-added compounds to complement already established phenolic extractions in these commercial plant species.

\section{Phytochemicals in essential oils and non-polar extractables from sumac}

Limited work has been done on determining the chemical composition of essential oils from sumac species. The few published studies have analyzed compounds in hydrodistillation oils from specific parts of the following small subset of $>250$ possible sumac species: $R$. semialata, $R$. coriaria, $R$. mysurensis, $R$. javanica, $R$. taitensis, $R$. thyrsiflora, and $R$. typhina. No other members of the Rhus genera have been reported on.

Surveys of essential oil compositions of Turkish $R$. coriaria plants using GC and GC-MS analysis have been performed $[15,16]$. A large number of compounds were tentatively identified in both studies (although details of structural confirmation by authentic standards are lacking, similar to the other two survey reports discussed below), of which the major components are summarized in Table 1. Of note, only two other studies have conducted surveys of non-phenolic phytochemicals in sumac, and are limited to the leaves of $R$. typhina [17] and the leaves and flowers of $R$. mysurensis [18].

Brunke et al. [15] identified the following major compounds in $R$. coriaria fruit oils, which gave hydrodistillation yields of $0.02-0.03 \%$ for separate samples from six different provinces in Turkey: $\alpha$ - 
pinene, limonene, octanal, $(E)$-hept-2-enal, nonanal, $(E)$-dec-2-enal, $\alpha$-/ $\beta$-humulene, $\alpha$-terpineol, $(E)$ undec-2-enal, hexahydrofarnesylacetone, pelargonic acid, $\beta$-humulene alcohol, carvacrol, heptacosane, palmitic acid, and nonacosane. Together, the saturated and unsaturated aliphatic aldehydes made up about $10 \%$ to $40 \%$ of the oils, based on relative GC-MS peak areas. The GC-MS analysis of a fatty acid methyl ester fraction obtained by transesterification of extracted $R$. coriaria seed fat showed that the triglycerides consist of significant quantities of oleic and linoleic acids (42\% and $31 \%$ of total fatty acids, respectively), with lesser amounts of palmitic acid (20\%) and stearic acid $(2.6 \%)$.

Higher yields $(0.11 \%$ to $0.32 \%)$ of essential oils were obtained by hydrodistillation from $R$. coriaria fruits from two regions of Turkey [16]. Geographic variation in the essential oil composition was observed. Comparable oil yields were realized from the hydrodistillation of leaves $(0.11 \%$ to $0.32 \%)$ and branches $(0.31 \%$ to $0.42 \%)$. Similar to the work of Brunke et al. [15], Kurucu et al. [16] found $\alpha$ pinene, limonene, octanal, $\beta$-humulene, $\alpha$-terpineol, $(E)$-undec-2-enal, and carvacrol as major compounds in the fruit oils. In contrast, $(E)$-hept-2-enal, $(E)$-dec-2-enal, $\beta$-humulene alcohol, heptacosane, palmitic acid, and nonacosane were not observed. Major components of the leaf oil were $\beta$-humulene $(0.3 \%$ to $17.0 \%)$ and a sesquiterpene hydrocarbon tentatively identified as patchoulane $(3.1 \%$ to $23.9 \%)$. The major constituents of the branch/bark oil were $\beta$-humulene $(12.4 \%$ to $21.9 \%)$ and the newly identified cembrene $(1 ; 10.7 \%$ to $26.5 \%)$.

Work on steam volatile constituents from leaves of $R$. typhina showed that of the monoterpenes, only a small number of alcohols in low concentration were found: $p$-menthadien-7-ol, linalool, terpineol, and geraniol [17]. The main sesquiterpene hydrocarbon characterized was $\beta$-humulene, followed by $\delta$ cadinene, $\gamma$-cadinene, $\alpha$-muurolene, $\alpha$-humulene, $\alpha$-copaene, and trans- $\beta$-bergamotene in order of decreasing concentrations. One of the most abundant components in the leaf oils was the diterpene alcohol phytol, as well as its oxidation product hexahydrofarnesyl acetone. Phytol is particularly of note given recent research showing it is a novel and effective vaccine adjuvant (a pharmacological agent added to a drug to increase or aid its effect) with little toxicity [18]. The authors noted that most of the constituents of $R$. typhina leaf oils seemed to originate from fat metabolism, including the fatty acids dodecanoic, tetradecanoic, pentadecanoic, hexadecanoic, and octadecanoic acids, and almost the complete series of $n$-hydrocarbons from heptane through triacontane. As well, small quantities of the furfural, benzyl salicylate, and the alcohols octanol, tetradecanol, hexadecanol, octadecanol, eicosanol, docosanol were observed.

In the leaf and/or flower (inflorescence) oils of $R$. mysurensis, 55 compounds were identified [19] (Table 1). Two of the major compounds in both oil types were the monoterpenes $\alpha$-pinene $(26.8 \%$ in leaf oil and $15.5 \%$ in flower oil) and limonene (26.2\% in leaf oil and $51.3 \%$ in flower oil). The other major components of the two oils were found to be sabinene and $\alpha$ - and $\beta$-eudesmol.

More targeted studies on non-phenolic phytochemicals in sumac have isolated and structurally

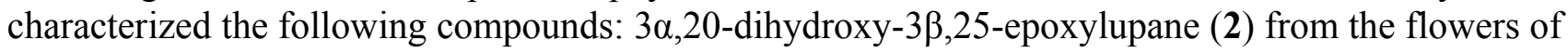
$R$. typhina [20]; allobutulin, $\alpha$-/ $\beta$-amyrin, campesterol, lupeol, and $\beta$-sitosterol from $R$. typhina leaves and branches [21]; rhuslactone (3) [22] and semialatic acid (4), semialactone (5), isofouquierone

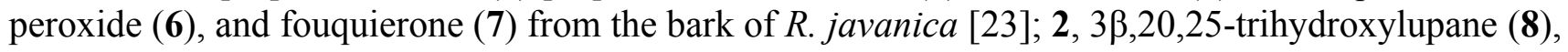

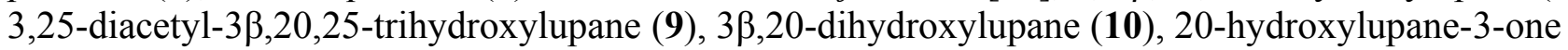
(11), and 20,28-dihydroxylupane-3-one (12) from the leaves of $R$. taitensis [24] and campesterol from $R$. thyrsiflora leaves [25]. Only two studies have investigated non-phenolic compounds from $R$. semialata, and the works involved isolation of just three compounds. Semialatic acid (4) was obtained 
from leaves [26], and lantabetulic acid and methyl lantabetulate were isolated from the stems [27].

\section{Concluding remarks}

To date, a number of individual aldehydes, fatty acids, long chain alcohols, terpenes and terpenoids, and waxes of commercial or bioactive potential in essential oils and non-polar extractables from selected members of the Rhus genera have been identified. Additional studies are needed to broaden the phytochemical database from other sumac species, and to better quantify the potential yields of these valuable compounds from the plants under natural and agriculturally managed conditions. A biorefinery concept applied to various sumac species could have leaves, stems and fruits extracted first with a non-polar solvent (e.g., hexane, supercritical $\mathrm{CO}_{2}$ ) to recover valuable fats, waxes, oils, sterols, terpenes, and other high-value phytochemicals, followed by an aqueous/alcoholic extraction to recover tannins, and any subsequent processing to utilize the lignocellulosic residues. 


\section{References}

1. R.A. Buchanan and F.H. Otey. Biosources Dig. 1 (1979): 176-202

2. N. Jordan, G. Boody, W. Broussard, J.D. Glover, D. Keeney, B.H. McCown, G. McIsaac, M. Muller, H. Murray, J. Neal, C. Pansing, R.E. Turner, K. Warner, and D. Wyse. Science 316 (2007): 1570-1571

3. J.P.H. van Wyk. Trends Biotech. 19 (2001): 172-177

4. A. Louwrier. Biotechnol. Appl. Biochem. 27 (1998): 1-8

5. A.J. Ragauskas, C.K. Williams, B.H. Davison, G. Britovsek, J. Cairney, C.A. Eckert, W.J. Frederick, J.P Hallett, D.J. Leak, C.L. Liotta, J.R. Mielenz, R. Murphy, R. Templer and T. Tschaplinski. Science 311 (2006): 484-489

6. B. Kamm and M. Kamm. Appl. Microbiol. Biotechnol. 64 (2004): 137-145

7. D. Tilman, J. Hill and C. Lehman. Science 314 (2006): 1598-1600

8. B.E. Van Wyk and M. Wink. Medicinal Plants of the World, Timber Press: Portland, USA. (2004)

9. F.A. Barkley. Ann. Missouri Bot. Gard. 24 (1937): 265-498

10. I.D. Clarke, J.S. Rogers, A.F. Sievers and H. Hopp. Tannin Content and Other Characteristics of Native Sumac in Relation to its Value as a Commercial Source of Tannin, United States Department of Agriculture: Washington, USA. (1949)

11. S. Rayne and G. Mazza. Plant Foods Human Nutr. 62 (2007): 165-175

12. M.R. Fazeli, G. Amin, M.M.A. Attari, H. Ashtiani, H. Jamalifar and N. Samadi. Food Contr. 18 (2007): 646-649

13. S. Giancarlo, L.M. Rosa, F. Nadjafi and M. Francesco. Nat. Prod. Res. 20 (2006): 882-886

14. P.R. Shewry, J.A. Napier and P.J. Davis. Engineering Crop Plants for Industrial End Uses, Portland Press: London, UK. (1998)

15. E.J. Brunke, F.J. Hammerschmidt and G. Schmaus. Flav. Fragr. J. 8 (1993): 209-214

16. S. Kurucu, M. Koyuncu, A. Guvenc, K.H.C. Baser and T. Ozek. J. Essent. Oil Res. 5 (1993): 481-486

17. H.J. Bestmann, B. Classen, U. Kobold, O. Vostrowsky, F. Klingauf and U. Stein. Phytochemistry 27 (1988): 85-90

18. S.Y. Lim, M. Meyer, R.A. Kjonaas and S.K. Ghosh. J. Imm. Based Ther. Vacc. 5 (2007): 3.

19. S. Srivastava, G.R. Mallavarapu, S.K. Rai, D. Singh, R. Mishra, S. Pandey-Rai and S. Kumar. Flav. Fragr. J. 21 (2006): 228-229

20. J. Schmidt, A. Porzel and G. Adam. Phytochemistry 49 (1998): 2049-2051

21. S.N. Hooper and R.F. Chandler. J. Ethnopharmacol. 10 (1984): 181-194

22. C.K. Sung, T. Akiyama, U. Sankawa and Y. Iitaka. Chem. Comm. (1980): 909-910

23. I.S. Lee, S.R. Oh, K.S. Ahn and H.K. Lee. Chem. Pharm. Bull. 49 (2001): 1024-1026

24. A. Yuruker, J. Orjala, O. Sticher and T. Rali. Phytochemistry 48 (1998): 863-866

25. K. Franke, M. Masaoud and J. Schmidt. Planta Med. 67 (2001): 477-479

26. N. Parveen, M.P. Singh, N.U. Khan, B. Achari and M.K. Logani. Phytochemistry 30 (1991): 2415-2416

27. S.C. Kuo, C.M. Teng, L.G. Lee, T.H. Chiu, T.S. Wu, S.C. Huang, J.B. Wu, T.Y. Shieh, R.J. Chang and T.C. Chou. Planta Med. 57 (1991): 247-249 


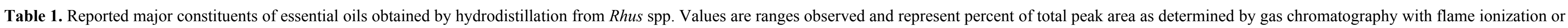

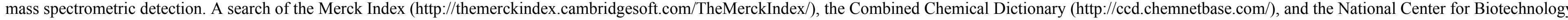

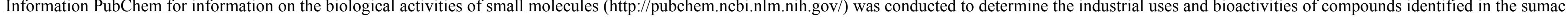

extracts.

\begin{tabular}{|c|c|c|c|c|c|c|c|c|c|}
\hline Species & & R. corl & iaria & & R. $m y s$ & urensis & R. typhina & & \\
\hline Plant portion & fruits & fruits & leaves & branches & leaves & flowers & leaves & & \\
\hline Reference & [15] & & {$[16]$} & & & 9] & [17] & Industrial uses & Bioactivities \\
\hline Aldehydes & & & & & & & & & \\
\hline$(E, E)-2,4$-decadienal & $1.0-5.8$ & $1.3-7.0$ & $<\mathrm{mdl}$ & $<\mathrm{mdl}-0.1$ & $\mathrm{nr}$ & $\mathrm{nr}$ & $\mathrm{nr}$ & & \\
\hline$(E, Z)-2,4$-decadienal & $0.6-2.4$ & $0.4-1.7$ & $<\mathrm{mdl}$ & $<\mathrm{mdl}$ & $\mathrm{nr}$ & $\mathrm{nr}$ & $\mathrm{nr}$ & & \\
\hline (E)-dec-2-onal & $2.9-22.2$ & $\mathrm{nr}$ & $\mathrm{nr}$ & $\mathrm{nr}$ & $\mathrm{nr}$ & $\mathrm{nr}$ & $\mathrm{nr}$ & & \\
\hline (Z)-dec-2-ёăal & $\mathrm{nr}$ & $9.9-42.4$ & $0.2-0.4$ & $<\mathrm{mdl}$ & $\mathrm{nr}$ & $\mathrm{nr}$ & $\mathrm{nr}$ & & \\
\hline (E)-hept-2-enal & $0.4-4.4$ & $1.9-2.5$ & $0.1-0.2$ & 0.05 & $\mathrm{nr}$ & $\mathrm{nr}$ & $\mathrm{nr}$ & & \\
\hline hexanal $\cong$ & $0.2-2.4$ & $0.1-1.3$ & $0.1-0.2$ & $0.2-0.6$ & $\mathrm{nr}$ & $\mathrm{nr}$ & $\mathrm{nr}$ & Used in fruit flavours and in perfumery. & Antifungal agents, insecticide. \\
\hline (E)-hex-2-gू⿹l & $<\mathrm{mdl}^{a}-0.2$ & $0.02-0.1$ & $0.03-4.4$ & $<\mathrm{mdl}$ & $\mathrm{nr}$ & $\mathrm{nr}$ & $\mathrm{nr}$ & & \\
\hline nonanal & $3.0-11.5$ & $10.8-13.1$ & $0.2-0.3$ & $0.3-0.4$ & $\mathrm{nr}$ & $\mathrm{nr}$ & 1.3 & Perfumery ingredient. Flavouring ingredient. & $\begin{array}{l}\text { Acts as an insect pheromone and may also be a pheromone in } \\
\text { humans. }\end{array}$ \\
\hline (E)-non-2-ènal & $0.5-1.6$ & $\mathrm{nr}$ & $\mathrm{nr}$ & $\mathrm{nr}$ & $\mathrm{nr}$ & $\mathrm{nr}$ & $\mathrm{nr}$ & & \\
\hline (Z)-non-2eginal & $\mathrm{nr}^{b}$ & $1.1-1.2$ & 0.1 & 0.1 & $\mathrm{nr}$ & $\mathrm{nr}$ & $\mathrm{nr}$ & & \\
\hline 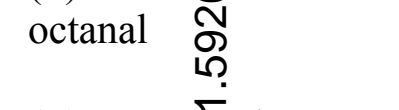 & $0.2-1.1$ & $0.8-1.3$ & $<\mathrm{mdl}$ & $0.05-0.1$ & $\mathrm{nr}$ & $\mathrm{nr}$ & $\mathrm{nr}$ & $\begin{array}{l}\text { Flavouring agent, used in eau-de-cologne and artificial citrus } \\
\text { formulations. }\end{array}$ & \\
\hline (E)-oct-2-Enal & $0.5-1.1$ & $1.0-1.3$ & 0.1 & 0.1 & $\mathrm{nr}$ & $\mathrm{nr}$ & $\mathrm{nr}$ & & \\
\hline (E)-undecÂ-enal & $0.3-2.3$ & $1.3-1.6$ & $<\operatorname{mdl}$ & 0.1 & $\mathrm{nr}$ & $\mathrm{nr}$ & $\mathrm{nr}$ & & \\
\hline Esters $\cong$ & $\mathrm{nr}$ & $\mathrm{nr}$ & $\mathrm{nr}$ & $\mathrm{nr}$ & $\mathrm{nr}$ & $\mathrm{nr}$ & $\mathrm{nr}$ & & \\
\hline 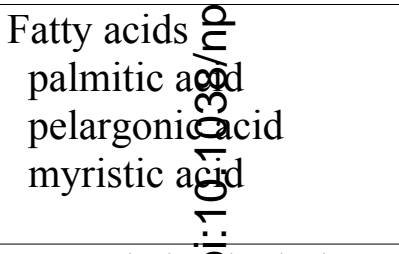 & $\begin{array}{c}0.8-5.1 \\
0.1-2.6 \\
\mathrm{nr}\end{array}$ & $\begin{array}{l}\mathrm{nr} \\
\mathrm{nr} \\
\mathrm{nr}\end{array}$ & $\begin{array}{l}\mathrm{nr} \\
\mathrm{nr} \\
\mathrm{nr}\end{array}$ & $\begin{array}{l}\mathrm{nr} \\
\mathrm{nr} \\
\mathrm{nr}\end{array}$ & $\begin{array}{l}\mathrm{nr} \\
\mathrm{nr} \\
\mathrm{nr}\end{array}$ & $\begin{array}{l}\mathrm{nr} \\
\mathrm{nr} \\
\mathrm{nr}\end{array}$ & $\begin{array}{c}11.1 \\
\mathrm{nr} \\
3.2\end{array}$ & $\begin{array}{l}\text { Food additives. Used in manufacture of surfactants, soaps, } \\
\text { plasticizers, polishing compounds, and thickening lubricating } \\
\text { oils. Emulsifying agents in foods and pharmaceuticals. Used } \\
\text { for waterproofing textiles. }\end{array}$ & $\begin{array}{l}\text { Skin penetrants. Enzyme inhibitors. Herbicides, insecticides, and } \\
\text { fungicides. }\end{array}$ \\
\hline
\end{tabular}

\section{Long chain}

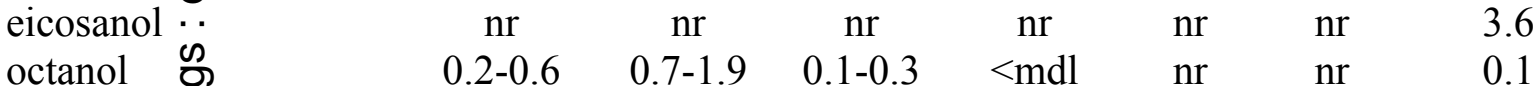

$0.2-0.6 \quad 0.7-1.9 \quad 0.1-0.3 \quad<\mathrm{mdl}$

$\mathrm{nr}$

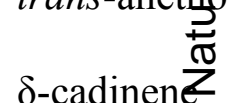

$<\operatorname{mdl}-2.4$

$\mathrm{nr} \quad \mathrm{nr}$

$\delta$-cadinol

-cadinol

carvone

$\mathrm{nr} \quad \mathrm{nr}$

$\mathrm{nr} \quad \mathrm{nr}$

$\mathrm{nr}$

cembrene

$\alpha$-eudesmol

$\beta$-eudesmol

$\begin{array}{cccc}\mathrm{nr} & 0.4-0.7 & 0.5-1.3 & 1.4-6.7 \\ \mathrm{nr} & \mathrm{nr} & \mathrm{nr} & \mathrm{nr} \\ 0.2-10.4 & <\mathrm{mdl} & 0.4-2.2 & <\mathrm{mdl}\end{array}$

$\begin{array}{ll}\mathrm{nr} & 0.4-0.7 \\ \mathrm{nr} & \mathrm{nr}\end{array}$

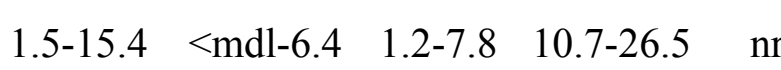

$\begin{array}{lcccc}\mathrm{nr} & \mathrm{nr} & \mathrm{nr} & \mathrm{nr} & 4.6 \\ \mathrm{nr} & \mathrm{nr} & \mathrm{nr} & \mathrm{nr} & 3.2\end{array}$

$\begin{array}{cccc}\mathrm{nr} & \mathrm{nr} & \mathrm{nr} & \mathrm{nr} \\ 0.2-10.4 & <\mathrm{mdl} & 0.4-2.2 & <\mathrm{mdl}\end{array}$
for waterproofing textiles.

Used in fruit flavours and in perfumery.

Used as a defoaming or wetting agent. Also used as a solvent for protective coatings, waxes, and oils, and as a raw material for plasticizers.

\section{Extensively used in flavour industry.}

Flavouring agent.

Flavouring ingredient.
Possesses carminative, expectorant, and insecticide properties Gastric stimulant.

Shows cytotoxic activity.

Antiseptic. Shows antimicrobial activity.

Antineoplastic agent, phytogenic. CNS stimulant, carminative agent, insecticide. Under development as a potato sprout inhibitor. 


\begin{tabular}{|c|c|c|c|c|c|c|c|c|c|}
\hline$(E, E)-\alpha$-farnesene & $\mathrm{nr}$ & $\mathrm{nr}$ & $\mathrm{nr}$ & $\mathrm{nr}$ & 1.1 & 0.4 & $\mathrm{nr}$ & & \\
\hline farnesyl acetone & $0.4-1.0$ & $<\mathrm{mdl}-0.5$ & $2.6-3.2$ & $1.8-4.9$ & $\mathrm{nr}$ & $\mathrm{nr}$ & $\mathrm{nr}$ & & \\
\hline geranyl acetone & $\mathrm{nr}$ & $1.4-1.9$ & $1.7-2.0$ & $0.2-0.4$ & $\mathrm{nr}$ & $\mathrm{nr}$ & $\mathrm{nr}$ & & \\
\hline phytone & $0.5-2.8$ & $<\operatorname{mdl}-0.9$ & $0.6-3.0$ & $<$ mdl- 0.2 & $\mathrm{nr}$ & $\mathrm{nr}$ & 0.4 & & \\
\hline$\alpha$-humulene & $0.8-1.5$ & $<\operatorname{mdl}-0.4$ & $0.2-1.4$ & $1.3-2.0$ & 1.2 & 1.8 & 0.1 & Perfumery & \\
\hline$\beta$-humulene & $4.0-13.8$ & $0.3-2.8$ & $0.3-17.0$ & $12.4-21.9$ & 6.6 & 9.4 & 6.3 & $\begin{array}{l}\text { Fragrance and flavouring agent. Starting material for synthesis } \\
\text { of other terpenoids. }\end{array}$ & $\begin{array}{l}\text { Active principle of extract of lemon balm. Used for its sedative and } \\
\text { antibacterial properties. Non-steroidal anti-inflammatory agent. }\end{array}$ \\
\hline$\beta$-humulene alcohol & $<$ mdl-2.9 & $\mathrm{nr}$ & $\mathrm{nr}$ & $\mathrm{nr}$ & $\mathrm{nr}$ & $\mathrm{nr}$ & $\mathrm{nr}$ & & \\
\hline$\alpha$-/ $\beta$-humulene oxide & $0.4-3.1$ & $\mathrm{nr}$ & $\mathrm{nr}$ & $\mathrm{nr}$ & $\mathrm{nr}$ & $\mathrm{nr}$ & $\mathrm{nr}$ & & \\
\hline $\operatorname{limonene}_{\overline{5}}$ & $0.4-1.1$ & $0.2-9.5$ & $2.1-3.7$ & $1.4-1.8$ & 26.2 & 51.3 & $\mathrm{nr}$ & $\begin{array}{l}\text { Extensively used in the perfumery and flavour industries and } \\
\text { in manufacturing of polymers and adhesives. }\end{array}$ & \\
\hline myrcene $\stackrel{N}{N}$ & $\mathrm{nr}$ & $\mathrm{nr}$ & $\mathrm{nr}$ & $\mathrm{nr}$ & 2.1 & 2.4 & $\mathrm{nr}$ & Flavouring agent. & \\
\hline (Z)- $\beta$-ocintàne & $\mathrm{nr}$ & $\mathrm{nr}$ & $\mathrm{nr}$ & $\mathrm{nr}$ & 6.9 & 3.0 & $\mathrm{nr}$ & & \\
\hline (E)- $\beta$-ocimene & $\mathrm{nr}$ & $\mathrm{nr}$ & $\mathrm{nr}$ & $\mathrm{nr}$ & 2.2 & 1.8 & $\mathrm{nr}$ & & \\
\hline patchoulaAd & $\mathrm{nr}$ & $0.4-1.8$ & $3.1-23.9$ & 4.9-8.4 & $\mathrm{nr}$ & $\mathrm{nr}$ & $\mathrm{nr}$ & & \\
\hline phytol ס & $\mathrm{nr}$ & $\mathrm{nr}$ & $\mathrm{nr}$ & $\mathrm{nr}$ & $\mathrm{nr}$ & $\mathrm{nr}$ & 31.9 & Preparation of vitamins $\mathrm{E}$ and $\mathrm{K}_{1}$. & Anticancer agent (colon and gastric cancer). \\
\hline$\alpha$-pinene $\overline{\mathscr{\omega}}$ & $1.1-3.8$ & $0.03-1.9$ & $0.3-3.6$ & $3.8-17.7$ & 26.8 & 15.5 & $\mathrm{nr}$ & & \\
\hline$\beta$-pinene 0 & $\mathrm{nr}$ & $0.03-0.4$ & $0.1-0.4$ & $0.4-2.7$ & 0.1 & $<\mathrm{mdl}$ & $\mathrm{nr}$ & & \\
\hline sabinene $\ddot{-}$ & $\mathrm{nr}$ & $\mathrm{nr}$ & $\mathrm{nr}$ & $\mathrm{nr}$ & 3.8 & 4.1 & $\mathrm{nr}$ & & \\
\hline$a$-terpineab & $0.5-2.4$ & $0.5-1.1$ & $0.5-1.1$ & $0.4-1.6$ & 0.1 & 0.1 & $\mathrm{nr}$ & & \\
\hline $\begin{array}{l}\text { Waxes 尺े } \\
\text { heptacosaffe }\end{array}$ & $0.9-5.7$ & $\mathrm{nr}$ & $\mathrm{nr}$ & $\mathrm{nr}$ & $\mathrm{nr}$ & $\mathrm{nr}$ & 1.1 & Lubricants and waxes. & \\
\hline pentacosa城 & $0.4-1.3$ & $\mathrm{nr}$ & $\mathrm{nr}$ & $\mathrm{nr}$ & $\mathrm{nr}$ & $\mathrm{nr}$ & 2.0 & & \\
\hline nonacosarẹ & $<\operatorname{mdl}-4.0$ & $\mathrm{nr}$ & $\mathrm{nr}$ & $\mathrm{nr}$ & $\mathrm{nr}$ & $\mathrm{nr}$ & $\mathrm{nr}$ & & \\
\hline \multicolumn{10}{|c|}{$<$ mdl=belog the unspecified method detection limit. ${ }^{b}$ nr=not reported. } \\
\hline \multicolumn{10}{|c|}{ 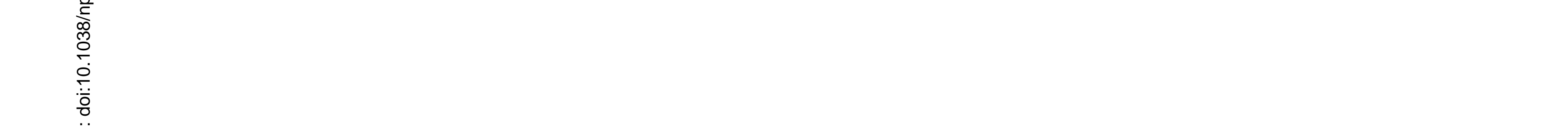 } \\
\hline \multicolumn{10}{|l|}{ 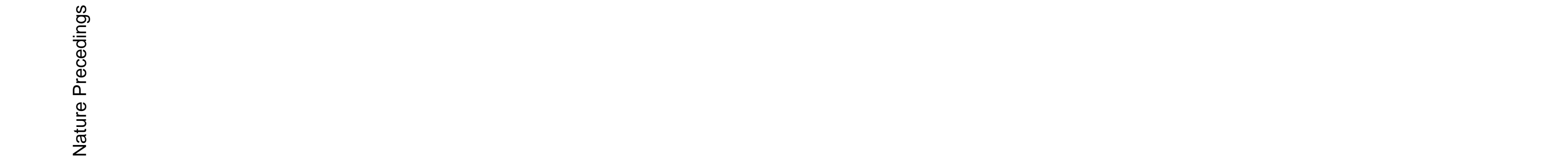 } \\
\hline
\end{tabular}



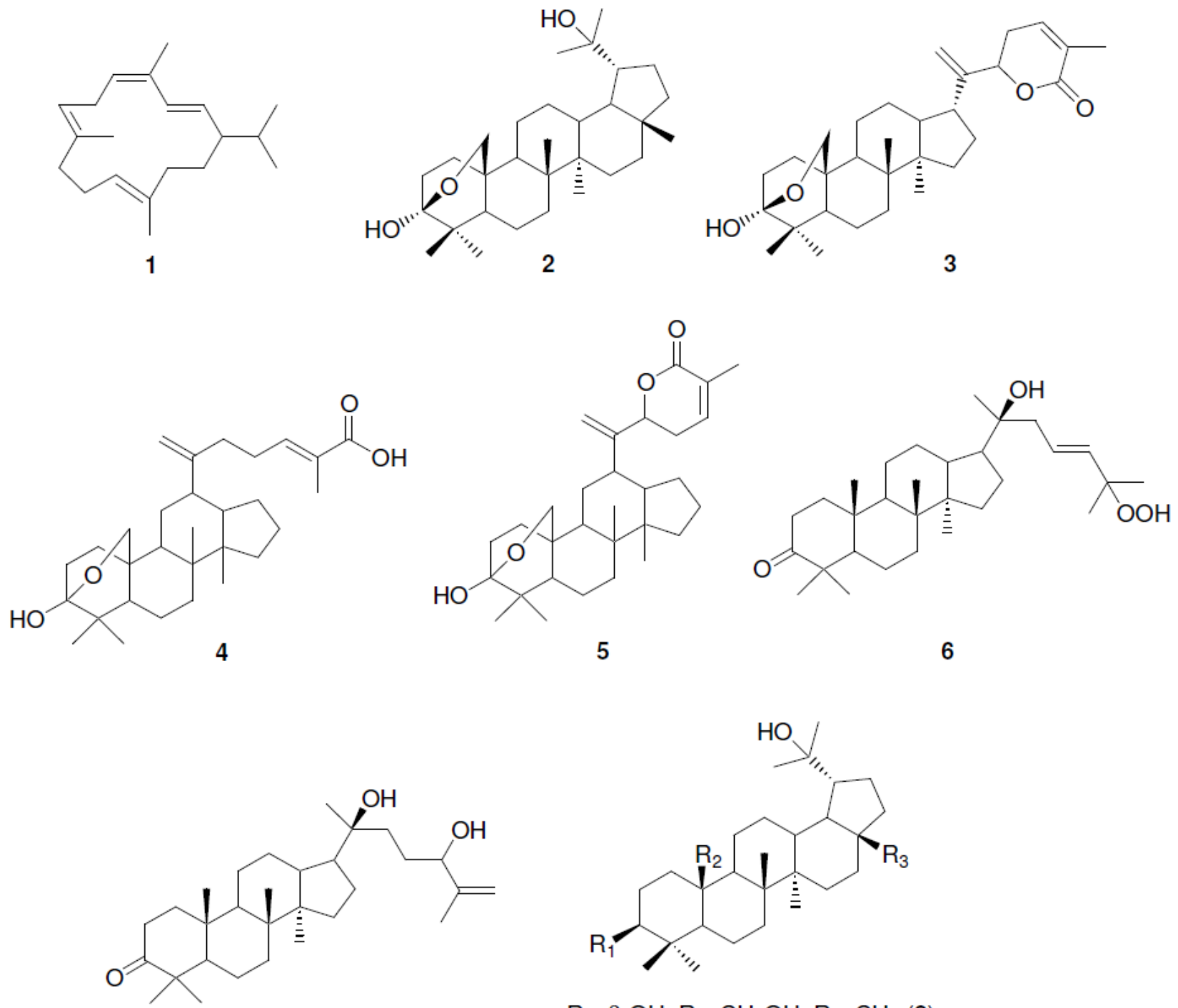

$$
\begin{gathered}
\mathrm{R}_{1}=\beta-\mathrm{OH}, \mathrm{R}_{2}=\mathrm{CH}_{2} \mathrm{OH}, \mathrm{R}_{3}=\mathrm{CH}_{3}(\mathbf{8}) \\
\mathrm{R}_{1}=\mathrm{OAc}, \mathrm{R}_{2}=\mathrm{CH}_{2} \mathrm{OAc}, \mathrm{R}_{3}=\mathrm{CH}_{3}(9) \\
\mathrm{R}_{1}=\beta-\mathrm{OH}, \mathrm{R}_{2}=\mathrm{CH}_{3}, \mathrm{R}_{3}=\mathrm{CH}_{3}(\mathbf{1 0}) \\
\mathrm{R}_{1}=\mathrm{O}, \mathrm{R}_{2}=\mathrm{CH}_{3}, \mathrm{R}_{3}=\mathrm{CH}_{3}(\mathbf{1 1}) \\
\mathrm{R}_{1}=\mathrm{O}, \mathrm{R}_{2}=\mathrm{CH}_{3}, \mathrm{R}_{3}=\mathrm{CH}_{2} \mathrm{OH}(\mathbf{1 2})
\end{gathered}
$$

Figure 1. Chemical structures for sumac-derived compounds referred to in the text. 